Международная Объединенная Академия Наук

\title{
Научный диалог: Вопросы философии, социологии, истории, политологии
}

\author{
Сборник научных трудов \\ по материалам \\ XVII международной научной конференции \\ 01 августа 2019 г.
}

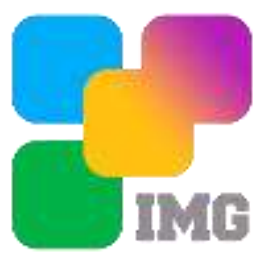

Санкт-Петербург 2019 
УДК 001.1

ББК 60

Научный диалог: Вопросы философии, социологии, истории, политологии. Сборник научных трудов по материалам XVII международной научно-практической конференции 1 августа 2019г. Изд. ЦНК МОАН, 2019. - 24c.

\section{SPLN 001-000001-0500-FI \\ DOI 10.18411/spc-01-08-2019 \\ IDSP sciencepublic-01-08-2019}

В сборнике научных трудов собраны материалы из различных областей научных знаний. В данном издании приведены все материалы, которые были присланы на XVII международную научно-практическую конференцию Научный диалог: Вопросы философии, социологии, истории, политологии

Сборник предназначен для научных работников, преподавателей, аспирантов и студентов.

Все материалы, размещенные в сборнике, опубликованы в авторском варианте. Редакция не вносила коррективы в научные статьи. Ответственность за информацию, размещенную в материалах на всеобщее обозрение, несут их авторы.

Информация об опубликованных статьях будет передана в систему Российского индекса научного цитирования (РИНЦ) и наукометрическую базу SPINDEX

Электронная версия сборника доступна на сайте ЦНК MOAН. Сайт центра: conf.sciencepublic.ru

УДК 001.1

ББК 60 


\section{Содержание}

РАЗДЕЛ І. ИСТОРИЯ

Рябов А.В. Курс на «социалистический реализм» (Из истории русского авангарда 19201930 гг.)

Трокаль Т.В. Проблема христианского оправдания применения насилия в процессе возникновения средневековой идеологии крестовых походов

Боброва Г.Е. Боевые бабы, революционные мегеры, роялистские фурии» (К вопросу о роли женщин в революциях Нового времени)

РАЗДЕЛ ІІ. ПОЛИТОЛОГИЯ.

Марабян К.П. Закавказский вектор политики НАТО

Фокина О.А. Сервисная политика государства как механизм политического маркетинга 


\section{РАЗДЕЛ І. ИСТОРИЯ}

\section{Рябов A.В. \\ Курс на «социалистический реализм» (Из истории русского авангарда 1920-1930}

гг.)

Санкт-Петербургский университет ГПС МЧС России

(Россия, Санкт-Петербург)

doi:10.18411/spc-01-08-2019-01

idsp: sciencepublic-01-08-2019-01

Термин «социалистический реализм» впервые прозвучал в 1932 году. Тогда же вышло в свет постановление «О перестройке литературно-художественных организаций». Однако смещение акцентов в сторону реализма и окончание короткой эпохи русского авангарда, намечается уже с середины 1920х годов. Большевистское правительство с осторожностью относилось к попыткам навязать “левое" искусство в качестве эстетической монополии. Происходящие в ИНХУКе события (призыв председателя О.Брика «бросить искусство и идти в производство»), заставили Наркомпрос РСФСР направить в ГАХН (под руководством которого работал ИНХУК) специальную комиссию во главе с А.С.Бубновым. Тщательно изучив все стороны деятельности Академии, комиссия признала ее работу неудовлетворительной. Были приняты меры для улучшения работы Петроградской Академии художеств, создается широкая сеть высших и средних художественных учебных заведений по всей стране (напр. в Ташкенте, Тбилиси и др.).

В 1923 г. Нарком А.В.Луначарский выдвигает лозунг “Назад к передвижникам”. 47-я Выставка этого старейшего художественного объединения состоялась в феврале 1922 года, а их декларация гласила: “Мы хотим с документальной правдивостью отразить в жанре, портрете и пейзаже быт современной России и изобразить всю трудовую жизнь его различных народностей”.

9-10 мая 1924 года при Отделе печати ЦК РКП(б) было проведено совещание, в работе которого приняли участие партийные работники, журналисты, критики, искусствоведы. Были обсуждены вопросы о задачах партии в руководстве литературой и искусством, об организации сил пролетарских писателей и об отношении к "попутчикам". Отдельным пунктом явилось осуждение деятельности журнала "На посту”. Журнал требовал полного отказа от старой культуры, как “буржуазнодворянской”. "Напостовцы” отрицали самое суть реалистических произведений образно отражать объективную действительность.

Некоторые вопросы искусства обсуждались и на XIII съезде партии большевиков, состоявшемся в мае 1924 года. Резолюции по этим вопросам призывали:

“... продолжить ведущуюся систематическую поддержку наиболее даровитых из так называемых попутчиков, воспитывающихся школой, товарищеской работой совместно с коммунистами".

“... ни одно литературное направление, школа или группа не могут и не должны выступать от имени партии”.

В июне 1925 года практически был положен конец дебатам о Пролеткульте. После того, как Оргбюро ЦК РКП (б) специальным постановлением приняло директивы, согласно которым Пролеткульт, хотя и сохранял за собой право считаться самостоятельной организацией, однако должен был подчиняться ВЦСПС. 
Таким образом, 1925 годом можно датировать окончание первого, революционно-преобразовательного периода в истории развития советского искусства. Пока за упразднение в живописи сюжета и содержания художникам-авангардистам приходилось бороться, можно было вдохновиться этим лозунгом и верить, что за запретной чертой скрыта какая-то новая истина. Но едва “левым” удалось представить свои изыскания в живописи, как нечто новое и положительное, зритель в своей основной массе потребовал искусства сюжетного, а не абстрактного. Союз “левых" с революцией выразился, прежде всего, в том, что в период всеобщего саботажа власти, “левые" пришли искренне служить революции. С существованием картины, казалось, было покончено навсегда, и они предложили вместо нее оформление празднеств, художественное проектирование новых вещей, выявление искусства на производстве массовых предметов потребления. Художник призывался оставить писать картины, и перейти к творчеству новой жизни, к производству вещей материальной культуры. Уход в производство был тем более современным, что с каждым месяцем все более обнаруживалось, что футуризм - это вовсе не пролетарское искусство, что дружба с Советской властью, которой они так настойчиво добивались, подходит к концу. А тот факт, что в Советской России государство было единым заказчиком и главным потребителем искусства, только ускорил этот процесс. Однако делать вывод, что опыт “левых" представителей искусства первых послереволюционных лет не удался, было бы крайне ошибочно. Итоговым документом, определяющим государственную политику по отношению к развитию искусства в России на этом временном отрезке можно считать Постановление ЦК РКП (б) “О политике партии в области художественной литературы".

Постановление вышло 18 июня 1925. Оно подчеркнуло необходимость решительной борьбы со всеми проявлениями буржуазной идеологии, критиковало примиренчество и капитулянтство в области литературы и искусства. Раскрывалась несостоятельность идеи о нейтральном искусстве. Была поставлена задача ориентироваться на творчество рабочих и крестьян, оказывая им всемерную помощь. Главной задачей в области литературы и искусства ставилась задача завоевания пролетарскими писателями и художниками идейной гегемонии. Постановление осуждало сектантство, комчванство и капитулянтство. Критика, не отступая ни на йоту от пролетарской идеологии, должна была проявлять величайший такт, осторожность, терпимость по отношению к творческим работникам, выразившим желание сотрудничать с Советской властью. ЦК РКП(б) требовал искоренить попытки некомпетентного административного вмешательства в литературные дела. "Распознавая безошибочно общественно-классовое содержание литературных течений, партия в целом отнюдь не может связать себя приверженностью к какому-либо направлению в области литературной формы... Партия должна высказываться за свободное соревнование различных группировок и течений в данной области. Всякое иное решение вопроса было бы казенно-бюрократическим псевдорешением".

При наличии в то время на художественном фронте самых разнообразных направлений и течений, положение о свободном соревновании между различными группировками можно расценивать как достаточно мудрый принцип руководства искусством, если, конечно, искусство вообще нуждается в государственном руководстве. Однако речь в Постановлении идет только о соревновании различных литературных форм. Что касается содержания произведений (будь то полотно художника или произведение литературы), то партия оставляет за собой право “безошибочно распознавать общественно-классовое содержание” и тем самым фактически объявляет искусство орудием своей идеологии и средством борьбы за 
власть. Этим документом заканчивается первый период развития Советского искусства и начинается второй, когда по мере укрепления политической власти коммунистов в стране все настойчивее намечается тенденция политизации и пролетаризации в искусстве.

$$
* * *
$$

1. Сергеев В.А. Борьба коммунистической партии против мелкобуржуазности в искусстве (1917-1932). Л., 1976. С.65

2. Борьба за реализм в изобразительном искусстве 20-х годов. Материалы, документы, воспоминания. M., 1962, C.173

3. К вопросу о политике РКП (б) в художественной литературе. М., 1924, С.106

4. Правда. 1925.18 июня.

5. О партийной и советской печати. М., 1954, С.347

Трокаль Т.В.

Проблема христианского оправдания применения насилия в процессе возникновения средневековой идеологии крестовых походов

\section{Российский Новый Университет (РосНОУ), колледж}

(Россия, Москва)

doi:10.18411/spc-01-08-2019-02

idsp: sciencepublic-01-08-2019-02

\section{Аннотация}

В центре внимания данной статьи - постепенное формирование идеологии средневекового крестоносного движения. Автор рассматривает процесс становления средневековой идеологии периода Крестовых походов и затрагивает главную проблему христианства в тот период - проблему оправдания применения насилия. На основании анализа раннехристианских церковных источников, а также трудов средневековых богословов, автор приходит к выводу, что процесс становления идеологии Крестовых походов осуществлялся в течении эволюционного развития всей западной христианской цивилизации.

Ключевые слова: крестовые походы, христианство, Ветхий Завет, Евангелие, Иоанн Креститель, «священная война», «справедливая война», Бернард Клервосский, Амвросий Медиоланский, Августин.

\section{Abstract}

The focus of this article is the gradual formation of the ideology of the medieval crusade movement. The author considers the process of formation of medieval ideology of the period of Crusades and touches upon the main problem of Christianity in that period - the problem of justifying the use of violence. Based on the analysis of early Christian Church sources and works of medieval theologians, the author comes to the conclusion that the process of formation of the ideology of the Crusades was carried out during the evolutionary development of the entire Western Christian civilization.

Keywords: Crusades, Christianity, the old Testament, the gospel, John the Baptist, "Holy war", "just war", Bernard of Clervos, Ambrose of Milan, Augustine.

В Средние века религиозное сознание во многом определило весь ход цивилизационного развития Западной Европы. Христианство выступило культурообразующим фактором, повлиявшим практически на все сферы жизни данной эпохи. Церковь же в данный период являлась одним из важнейших социальных институтов.

С началом эпохи Крестовых походов роль церкви в повседневной жизни средневекового общества значительно возросла. Духовенство было той направляющей силой, под воздействием которой крестоносцы покоряли Ближний Восток и одерживали победы над врагом. Не подлежит сомнению, что роль духовной идеологии западного христианства была в тот момент громадной, во многом благодаря многочисленным духовным проповедям католических священников - от папы Урбана II до Петра Амьенского (Пётр Пустынник). Их пламенные проповеди помогли участникам Первого крестового похода захватить Иерусалим.

Однако, рассматривая историю создания идеологии крестовых походов, нельзя не обратить внимание на то, что создавалась она на протяжении почти 10 веков существования христианства как такового и путь возникновения её был весьма непрост. 
Начать с того, что в Ветхом Завете имеется чёткий императив, запрещающий убийство (Исх., 20:13), а также описан прецедент совершённого Каином кровопролития (Быт.,4:8-13), трактуемый исключительно негативно. Что же касается Евангелия, то его базовым компонентом выступает принцип любви к Богу и ближним (Мк.,12:28-34). Центральная проповедь Христа - о покаянии, отказе от мира греха ради обретения Царствия небесного. Идеалом является мир святости, в котором нет места вражде.

Но при всём при этом в Ветхом Завете идея антимилитаризма сочетается с дихотомией «свойчужой» по религиозной оппозиции. Ветхозаветные повествования изобилуют примерами борьбы иудеев с соседями, в которых обе стороны проявляли жестокость и вели длительные войны, победу в которых, по версии ветхозаветных авторов одерживали более ревностные в религиозном и более совершенные в нравственном плане иудеи. Если же враги, в силу численного превосходства и профессиональных качеств одерживали верх над иудеями, то поражение рассматривалось как результат «отхода от веры» и возвращения иудейских племён к язычеству. Это время постоянных военных стычек с соседями и междоусобиц, длившееся с 1445 по 1045 год до нашей эры, получило название эпохи Судей. Это был первый опыт «священной войны» в истории человечества.

В ту эпоху ревностное следование религиозным постулатам позволяло верующим иудеям разделить войны на «беззаконные» и «справедливые» а последние считать не только как санкционированные сакральной земной властью (в тот период это были иудейские первосвященники), но как ведомые самим Богом посредством избранного народа.

Спустя сотни лет, Евангелие снимает ветхозаветный этнический компонент с понятия «избранный народ» исходя из наднационального принципа консолидации верующих на религиозной основе. Возникает идея пацифизма, чётко представленная в призыве любить обидчиков и молиться за них, а также постоянно прощать согрешающих (Евангелие от Матфея, 5:44; 6:14; 18:21-22). Идея антимилитаризма очевидна из постулирования статуса миротворцев, которые «будут наречены сынами Божиими» (Евангелие от Матфея, 5:9).

Однако при этом приоритет отказа от насилия сочетается с констатацией факта несовершенства мира и греховности человеческой природы, т.к. Спаситель «пришёл призвать не праведников, но грешников к покаянию» (Евангелие от Луки, 5:32). Исходя из этого, Христос не отверг мытарей, презираемых за службу иноверцам, а Иоанн Креститель проповедовал им не отказ от профессиональной практики, а честное следование долгу и недопустимость злоупотреблений служебными полномочиями (Евангелие от Луки, 3:13). В русле этого морального принципа Евангелие позиционирует возможность воинской службы для верующих: «Спрашивали его (Иоанна Крестителя) также и воины: «А нам что делать?» И сказал им: «Никого не обижайте, не клевещите и довольствуйтесь своим жалованьем» (Евангелие от Луки, 3:14). Необходимо также отметить, что Иисус тоже хвалил римского сотника за веру и не упрекал за род деятельности (Евангелие от Матфея, 8:15).

Евангельский идеал миролюбия нашёл воплощение в раннехристианской культуре I - нач. IV в., где доминировал пацифизм. Многие ранние христиане заняли позицию неприятия воинской службы. Характерный для имперской римской культуры воинский культ имел неприемлемые для христиан формы: от солдат требовалось почитание изображений монарха, чьё происхождение считалось божественным и поклонение языческим богам. На практике это имело не столько религиозное значение, сколько служило своеобразным актом лояльности властям.

Главная же причина неприятия воинского служения была в акте убийства. Первым христианам гораздо легче было отдать свою жизнь за Христа, обретая этим Царство Небесное, чем отнять её у другого, идя против заповеди Божией «не убий».

Первые христиане отвергали оружие и насилие как таковое. Это было связано с тем, что военная служба в Римской империи не была обязательной, а армия состояла в основном из наёмников. Таким образом, христианин не нарушал Божий закон и законы империи, отказываясь брать в руки оружие. В раннехристианской культуре доминировало негативное отношение к военным (по лат. milites), сформированное апологетами раннехристианской церкви под влиянием евангельского идеала миролюбия.

В IV - V вв. происходит слом европейской цивилизационной парадигмы, связанный с комплексным кризисом римской культуры и усилением натиска варваров в ходе «великого переселения народов». В этих условиях универсальность христианства как религии спасения, не имевшей этических, политических, социальных границ, устоявшей под гнётом гонений I - нач. IV вв., а также государственная поддержка церкви, начатая в начале IV в. императором Константином, способствовали быстрому притоку новообращённых.

Потребность поддержания порядка и безопасности христианства и империи в целом, сливших воедино, в условиях усиления военной угрозы актуализировали проблему milites в христианской культуре. Во времена ранних гонений на христиан, при комплектовании римской армии наёмникамиязычниками, верующий мог строго следовать букве 10 заповедей.

Однако в начале V в. социальное, политическое и религиозное положение империи этого не позволяли - христиан становилось всё больше. Догматически война продолжает оставаться злом, убийство - страшным грехом. Но обладавший сакральной властью правитель, выполняя заповедь «не 
убий», непротивлением злу насилием только поощрял бы агрессоров и был бы повинен в беззакониях против своих подданных, имея возможность их предотвратить. Таким образом возникала духовноидеологическая дилемма - выполняя букву Божьего закона, монарх нарушал его суть. Поэтому постепенно в богословском мире возникают концепции, всё более укреплявшиеся с ростом военной угрозы со стороны язычников-варваров, о допустимости применения насилия христианами для защиты сограждан и собственного государства.

Эволюция воззрений на проблему войны в христианской культуре впервые прослеживается в трудах Амвросия Медиоланского (334-397), писавшего, что в «в делах военных, думается, нужно обращать внимание на то, справедливы ли эти войны или нет». Перевод проблемы в этическую плоскость позволил сделать предметом исследования не насилие как явление, а смысловую мотивацию его применения. Категория справедливости, определяющая концепцию св. Амвросия, соотнесена с евангельской ценностно-нормативной системой, выступающей в качестве эталона.

Исходя из принципа легитимности и сакральности власти, характерного ещё для раннего христианства, св. Амвросий наделял правом инициирования боевых действий правителей или лиц, которым делегированы подобные полномочия. Он позитивно оценивал защиту Италии от варваров императором Валентинианом-мл., который, «когда услышал, что варвары приблизились к границам Италии, и, опасаясь, чтобы неприятель не напал на государство, спешил вернуться, взяв на себя нашу опасность и оставив покой», то есть руководствовался идеями долга и любви к ближним. Его сыну Грациану, по преданию, епископ как представитель церкви написал исповедание веры, «предсказал победу над врагами и благословил его знамёна». Простых воинов св. Амвросий, повторяя слова Иоанна Крестителя, призывал «довольствоваться жалованьем, не вымогая силой иных доходов». Епископ не осуждал деятельность, направленную на поддержание общественного порядка внутри страны, защиту родины от агрессоров или помощь союзникам, то есть честное выполнение своего воинского долга.

Так, постепенно, в христианской западной культуре возникает принципиально новая концепция «законной» (справедливой) войны (bellum justum), которую развил и конкретизировал ученик св. Амвросия - блаженный Августин (354-450). Базой его теории является противопоставление града небесного, выступающего в качестве религиозного эталона, и града земного, погрязшего в грехах и пороках.

По мнению Августина, мир без войны - идеал, недостижимый в граде земном, и даже несмотря на то, что война как явление есть грубое отклонение от божественных заповедей, проблема войны не утратит актуальности даже в христианском социуме: «никогда люди не будут жить в безопасности, не боясь нападений, угрожающих жизни». Отсюда необходимость создания адекватных механизмов адаптации христианской культуры к фактору насилия извне. Государство в этой ситуации выступает инструментом исправления человеческой греховности. Обеспечивая правопорядок, оно вынуждено опираться на силу. Долг верующих при этом - поддерживать легитимную власть и её институты. Таким образом впервые в культуре христианства теологически было обосновано право христиан брать в руки оружие и совершать насилие.

Констатируя право христиан на применение насилия, бл. Августин, вслед за св. Амвросием, классифицировал войны исходя из смысловой мотивации их инициаторов. Боевые действия начатые из страсти к господству, алчности, для угнетения, греховны по своей природе и позиционируются как разбой. Напротив, возвращение похищенного имущества и возмездие за нанесённый ущерб есть формы восстановления справедливости. Ещё более правомочны войны оборонительные для защиты себя и своего имущества. Комментируя Пятикнижие, епископ высказался ещё более конкретно: справедливая война носит оборонительный характер вообще (даже если она ведётся на территории противника) и предпринимается для наказания злодеев, ради восстановления частных прав, находящихся под угрозой их нарушения.

Новым для христианской культуры стало и восприятие насилия бл. Августином не только как следствия греха, но и как средства от него. Справедливая война призвана не только наказать виновных, но и предотвращать потенциальные угрозы. Регулятивная функция государства, призванная поддерживать социальную стабильность, позволяет применять силу не только post factum, в ответ на уже совершённое злодеяние, но и в качестве превентивной меры пресечения беззаконония.

Таким образом, постепенно в западно-христианском ценностно-мировоззренческой системе формируется новый социопсихологический стереотип milites - теперь уже как защитника христианской веры и единоверцев, пресекающего беззакония, при этом опирающегося на сакральную, легитимную с точки зрения Церкви власть.

Были сформированы следующие духовные критерии, определяющие право христиан на применение насилия:

1. Справедливая война неизбежна, если все другие мирные средства были исчерпаны;

2. Ц Цель справедливой войны - пресечение беззакония и обеспечение правосудия;

3. Воюющие исходят из христианских мотивов любви к ближнему (при этом в условиях войны христианская любовь, желание исправления и спасения души врага - понятия 
умозрительные, не противоречащие необходимости телесно умертвить противника в бою);

4. Инициирование боевых действий и руководство осуществляется легитимным монархом или лицами, которым делегированы данные полномочия. На власть возложена и ответственность за справедливость применения силы в религиозном и правовом аспектах;

5. Методы войны должны быть милосердны, исключающими несоразмерное применение насилия и корыстную мотивацию;

6. Духовенство не может участвовать в боевых действиях.

Таким образом, св. Амвросий Медиоланский и бл. Августин в своих трудах ввели в христианскую культуру концепцию "справедливой войны", выступающую в качестве эталонной категории, которая легла в основу западной церковной доктрины о войне и воинах. В рамках сформированной модели было дано догматическое обоснование легитимности воинской практики в религиозном аспекте и определены её критерии, направленные на минимизацию насилия и ущерба от него. Подобный синтез был определён ходом цивилизационного развития Западной Европы, и стал ответом христианского государства на фактор внешней военной угрозы.

В более поздний период проблема освещённого церковью насилия проявилась в работах Хинкмара Реймсского. Во второй половине IX он сочиняет трактат - некое «зерцало государей», где, многократно цитируя св. Августина, Иеронима, Амвросия, Григория Великого, подчеркивает: власть короля не абсолютна, а подчинена божественному праву. Она дана ему Богом ради выполнения особой миссии - вести народ к спасению. Функции государя в данном сочинении многообразны: они включают правосудие, покровительство, поддержание мира, а также ведение войны. В своих последующих сочинениях Хинкмар делает упор именно на этом аспекте функций короля. Он напоминает, цитируя св. Августина, что война может быть справедливой, если вдохновлена Богом, и тогда тот, кто убивает, - не убийца. Следовательно, те, кто служит с оружием в руках, этим фактом не гневят Бога, как показал автор «Града Божия». Не доходя, как папа Лев IV, до обещания мученических венцов тем, кто погибнет в справедливом бою, Хинкмар тем не менее оправдывает войну, когда к ней вынуждает необходимость защититься от неверных. Эта защита христианства, вверенная королю, может задним числом оправдать даже агрессивную войну, если она была полезной для христианского мира.

К началу первого крестового похода (1096 г.) принципиально новым явлением в христианской культуре стала сакрализация войн, инициированных межконфессиональным антагонизмом. Вынужденная и осторожная тенденция милитаризации христианства, направленная на поддержание правопорядка, со времён св. Августина претерпела длительную эволюцию, и к началу эпохи крестовых походов обрела характер воинственного мессианства. К этому моменту западное духовенство уже имело положительный опыт применения milites в процессе христианизации Европы и отражении нашествий арабов, норманнов и венгров. Следующим шагом стали притязания папства на объединение и расширение христианского мира в контексте средневекового принципа универсализма. Отсюда закрепление существовавшего ранее негативного стереотипа чужака-иноверца как служителя демонических сил на догматической основе. Таким образом вооружённое противостояние с иноверцами получило сакральный статус, расцениваясь как рыцарский долг на службе Богу.

Однако данная идеологема явно противоречила идее справедливой войны св. Августина, где насилие выступает лишь в качестве исключительной меры. Необходимо было создать новую идеологическую концепцию, оправдывавшую расширение христианского мира вооружённым путём.

Новое для того времени идеологическое обоснование захватнических походов появляется под названием "священная война" (это понятие было разработано папой Григорием VII (1073 - 1085), появляется в западноевропейских хрониках и актовых материалах к концу ХІ в. Это война за идеалы христианской веры, её распространение и защиту от внешних и внутренних врагов, и поэтому её ведение осуществлялось высоким церковным авторитетом или религиозным вождём. Священная война отличается от "справедливой войны" причинами, задачами, интенсивностью и продолжительностью. Впрочем чёткие различия между священной и справедливой войнами так и не были оформлены и на практике легко размывались, и в каждом конкретном случае справедливая война могла быть истолкована как священная.

Немецкий историк А.Ваас считал, что крестоносному мышлению свойственны следующие представления:

1. Х Хистос - предводитель крестоносцев.

2. Справедливость Божия - гарантия победы.

3. Крестоносцы - избранный народ, подобно героям Ветхого Завета.

4. Их задача - отвоевать для Христа то, что ему принадлежало.

5. За это они обретают вечное спасение.

6. На их стороне сражаются ангелы и святые.

Крестовые походы неизменно удовлетворяли основному принципу справедливой войны, так как велись ради отвоевания утраченного или защиты от агрессии. В то же время крестовый поход был 
подобен священной войне: его участники выступали на стороне Церкви и политической целостности христианского мира и на защиту Христа как царя единого христианского государства. Таким образом, священная война, т.е. война в интересах Церкви,

становилась не только допустимой, но и желательной.

Отличием крестового похода от священной войны было то, что возглавлял его не светский правитель (император или король), а папа Римский.

Впрочем, верховное руководство в обоих случаях брал на себя папа, который нередко объявлял священную войну и назначал главнокомандующего - например, предводителем 7-го (1248) и 8-го (1270 г.) крестовых походов был французский король Людовик IX Святой. Папа становился и сюзереном завоёванных земель.

Упомянутый перелом в сознании внёс свои изменения и в христианскую миссию в языческих землях. Далеко не всегда цель (обращение язычников в христианство) бывала достигнута мирными методами (проповедь). Возникла и получила признание формула "compelle intrare" означавшая насаждение христианства любыми, даже насильственными методами. В сфере канонического права проблему насилия (и войну как один из видов его проявления) исследовал Грациан (ум. около 1140 г.). Используя понятие "меч" как метафору общего понятия "сила принуждения", он говорил о духовном мече (духовное принуждение - интердикт, отлучение) и мече материальном (физическое принуждение, насилие) и оправдывал использование последнего Церковью.

Идея священной войны воплотилась в практику в конце XI в. Рыцари и прочие воины христианского мира, поощряемые церковными властями, прекратили междоусобицы и двинулись на Восток, чтобы сражаться с неверными. В качестве вознаграждения их ожидали "отвоёванные" земли а также церковные бенефиции - отпущение всех грехов, обещание райской жизни за гробом, минуя чистилище, а в особых случаях - даже причисление к лику святых.

К XIII веку основные привилегии крестоносцев были уже определены, причём им предоставлялась защита со стороны закона, так как многие из этих привилегий имели отношение к юридическим вопросам. Кроме индульгенций и защиты семьи и имущества они включали в себя также отсрочку выполнения вассальных обязательств или ответа перед судом до возвращения крестоносца домой или же ускорение судебного разбирательства перед отправлением в поход; предоставление отсрочки выплаты долгов или процентов; освобождение от пошлин и налогов; разрешение священнику получать доход с прихода во время своего отсутствия и дозволение рыцарю продавать или закладывать свой феод или неотчуждаемую собственность с целью получения денег для участия в походе; снятие церковного отлучения; разрешение вступать в сделки с отлученными от Церкви лицами и освобождение от последствий отлучения; возможность использовать крестовый обет для замены другого, ещё не выполненного обета и право выбрать себе личного исповедника, обладающего властью отпускать грехи.

Всё это, по замыслу идеологов крестоносного движения, должно было сподвигнуть всех желающих на дальнейшее завоевание ближневосточных территорий. Однако тут возникла непредвиденная сложность: большинство рыцарей принимали обеты крестоносцев не на постоянной основе, а временно, лишь на определённый срок, по истечении которого они возвращались в Европу. Таким образом, перед папской курией возникла необходимость создания духовно-рыцарских орденов воинских подразделений, расквартированных в Святой земле на постоянной основе.

Но для данной категории воинов нужна была особая идеология, поскольку эти рыцари вели совершенно особый образ жизни, заметно отличающий их от всех прочих крестоносцев, дававших временные обеты, и уж тем более отличающийся от того образа жизни, который вели все рыцари того времени. Такая идеология нужна была в первую очередь и самим крестоносцам, так как она служила обоснованием их сурового образа жизни, связанного со строгой дисциплиной, как религиозной, так и военной.

Создателем идеологии рыцарей крестоносных орденов по праву считается Бернард Клервосский (1091-1153) - французский средневековый богослов, мистик, общественный деятель, цистерцианский монах. Он считается одним из основателей духовно-рыцарского ордена тамплиеров, в частности под его влиянием на соборе в Труа 1128 года был принят устав ордена. Он был вдохновителем второго Крестового похода 1147 года.

Бернард был другом магистра ордена тамплиеров Гуго де Пайена и именно по его просьбе он написал свой знаменитый трактат «Похвальное слово новому рыцарству» («De laude novae militiae»). Данный трактат, без сомнения, является краеугольным камнем всей крестоносной идеологии.

Этому новому рыцарству, появление которого святой Бернар приветствовал в своей книге в самых восторженных выражениях, он отводил двоякую роль: сражаться с духом зла и с "противниками из плоти и крови".

Смысл новой идеологии крестоносцев сводился к следующему:

1. Если бы от неверных можно было защититься иными средствами, нежели мечом, то лучше было бы не проливать их крови; но поскольку неверные представляют угрозу духовному наследию христианства, то необходимо всеми силами стремиться воспрепятствовать им уничтожить это наследие. 
2. Святая Земля - не просто территория, она, по сути, принадлежит Иисусу Христу, который крестил ее своей святой кровью ради спасения всего человечества, поэтому невозможно оставлять эту землю в руках язычников;

3. Война в Святой Земле ведется не ради территориальных завоеваний, еще меньше ее следует считать столкновением народов: это борьба за защиту Святых мест, колыбели христианства, особенно Гроба Господня.

4. Смерть и убийство врагов веры - это не смерть и убийство обычных людей (т.е. смертный грех согласно Евангелию). Это уничтожение "носителей зла", и таким образом, оно грехом не является: "Если он убивает делающего зло (врага христианства), то не становится человекоубийцей, а, если можно так выразиться, уничтожителем зла."

5. Смерть крестоносцев в бою также не является грехом, а павших воинов в загробной жизни ждёт рай и посмертная слава: "Ибо убить или самому быть убитым во имя Христа - не грех, а скорее дорога к славе. В первом случае рыцарь побеждает во имя Христа, а во втором - воссоединяется с ним. Господь принимает смерть врага, оскорбившего его, и еще более охотно отдает себя утешению своего павшего рыцаря."

6. При существющих условиях только рыцари Христа, движимые глубокой верой и абсолютным бескорыстием могут принять на себя задачу возвратить и защитить колыбель христианства, а не светские рыцари, тщеславные и алчные.

В своем произведении Бернард проводит линию противопоставления мирских рыцарей, которых он без жалости именует "шайкой мошенников и негодяев" рыцарям-тамплиерам. Обращаясь к рыцаряммирянам, он говорит:

"Вы рядите своих лошадей в шелковые попоны и какими только тряпками не покрываете свои кольчуги. Вы разукрашиваете копья, гербовые щиты и седла инкрустируете золотом, серебром и каменьями удила и стремянные ремешки. Вы роскошествуете до самой смерти и гоняетесь за своей погибелью со всем рвением, бесстыдством и заносчивой дерзостью. Разве мишура пристала латам рыцаря или убору дамы? Или вы думаете, что золото повернет вспять оружие ваших противников, драгоценности принесут вам пощаду, а шелк - избавление? Нам часто приходилось слышать, что в бою необходимы три вещи: рыцарь должен выказывать бдительность в обороне, проворство в верховой езде и стремительность в атаке. Вы же причесываетесь, подобно женщинам, стараясь привлекать своей внешностью, ваши ноги путаются в длинных и широких туниках, вы прячете ваши руки, изнеженные и мягкие, в просторных рукавах. И, вырядившись подобным образом, вы вступаете в бой

по самому суетному поводу: из-за необузданного гнева, жажды славы или вожделения к мирским благам".

Одновременно с этим Бернард всячески превозносит и восхваляет скромность, послушание и аскетизм рыцарей-крестоносцев (в данном случае тамплиеров):

«Они живут и действуют по воле своего командора; они носят ту одежду, которую он им дает, не ища ни иного платья, ни иной пищи. Они остерегаются любого излишества в еде и одежде, довольствуясь лишь самым необходимым. · Они живут сообща, обходясь без женщин и детей. И чтобы не иметь изъяна против ангельского совершенства, они селятся под одной крышей, не имея никакого личного имущества, объединенные своим Уставом в почитании Господа. Не сыщешь среди них ни лентяя, ни праздного гуляки; когда они не присутствуют на службе - что бывает очень редко - или не вкушают свой хлеб, вознося благодарения небесам, они трудятся, починяя одежду или конскую сбрую, изорванную и искромсанную. Либо же они исполняют то, что повелел им их магистр или что требуют нужды их дома. Ни один из них не находится в подчинении у другого, они почитают лучшего, но не знатнейшего. Они проявляют учтивость по отношению друг к другу и, помогая один другому, следуют заветам Христа."

В своём произведении Бернард обосновывает смысл крестоносного служения и духовную суть принятия обетов крестоносца:

"Говорю вам, рыцарь Христа может разить с уверенностью и с еще большей уверенностью может он умирать, ибо он служит Христу, когда сражается, и служит себе, когда погибает. И не напрасно носит он меч, ибо послан Господом, чтобы наказать злодеев и славить праведных. Если он убивает делающего зло, то он не человекоубийца, но, если можно так сказать, убийца зла.

Он воистину Христов мститель для злодеев, и по праву считается защитником христиан. И если ему самому суждено быть убитым, мы знаем, что он не сгинет, а будет пребывать в мире и спокойствии. Когда он убивает, то во благо христово, а когда погибает - для собственного блага.

Смерть язычника прославляет христианина, ибо прославляет Христа; в то время как смерть христианина дает Царю возможность показать свою щедрость, вознаграждая своего рыцаря. В первом случае справедливые возрадуются, увидев свершенную справедливость, а во втором скажут: Воистину справедливость вознаграждается, воистину Господь Бог на земле судья. Я не хочу сказать, что язычников следует убивать при наличии другого способа помешать им преследовать верующих, но теперь лучше уничтожить их, чем позволить силе грешников возобладать над праведниками, а праведникам погрязнуть в пороке." 
Таким образом, на основании анализа трудов как раннесредневековых христианских богословов, так и религиозных деятелей периода Крестовых походов, можно сделать вывод о том, что проблема духовного оправдания применения насилия оставалась актуальной на протяжении всего цивилизационного развития христианской Европы. По мере того, как её актуальность становилась всё более и более очевидной, духовным деятелям Церкви приходилось создавать идеологию, не просто оправдывающую применение насилия, но полностью соответствующую их практическим целям и задачам.

\section{$* * *$}

1. Августин Аврелий. О граде Божием// Августин Аврелий. Творения: В 4 т. Т 3-4. СПб.: Киев. 1998. XIX, 7.

2. Амвросий Медиоланский. Об обязанностях священнослужителей. М.: Рига, 1995, С. 176.

3. Заборов М.А. «История Крестовых походов в трудах западногерманских историков»//«Византийский временник», Т.18 (43). 1961. С. 291-311.

4. История крестовых походов (под редакцией Джонатана Райли-Смита). М.: "Крон-Пресс", 1994, С. 86-87.

5. "Цистерцианские отцы": номер 19, труды Бернара Клервоского: Том 7, трактаты III, в переводе Конрада Гринии, издательство "Cistercian Publications", Каламазу, Мин., 1977. 


\title{
РАЗДЕЛ ІІ. СОЦИОЛОГИЯ
}

\author{
Боброва Г.Е. \\ Боевые бабы, революционные мегеры, роялистские фурии» (К вопросу о роли \\ женщин в революциях Нового времени)
}

Новокузнеикий институт (филиал) ФГБОУ ВО «Кемеровский государственный

университет»

(Россия, Новокузнецк)

doi:10.18411/spc-01-08-2019-03

idsp: sciencepublic-01-08-2019-03

В конце ХІХвека в фокусе внимания исследователей оказался феномен толпы. В Европе сложилось несколько центров его изучения: Франция, Италия и Россия.

Обращение ученых данных стран к указанному явлению не было случайным. Франция на протяжении века, начиная с 1789 года, была эпицентром всех социальных и национальных потрясений, будораживших Европу. По словам нашего современника С. Московичи, «революции и контрреволюции следовали одна за другой, и террору и разрушениям, казалось, не будет конца. Главным действующим лицом этих событий была толпа. Само понятие толпы было введено Г. Ле Боном при изучении Французской революции. Таким образом, реальное положение дел в стране, беспорядки, производимые толпами, подтолкнули французских исследователей: Г. Ле Бона, Ж.Г. Тарда, О. Кабанесса, Л. Насса, к изучению этого феномена.

Итальянские ученые: Ч. Ломброзо, Р. Ляски, С. Сигеле активно разрабатывали проблему преступности, в том числе коллективной, как характерной черты революционных эпох. «Изучение преступления толпы, - писал С. Сигеле, - очень интересно, особенно в конце века, когда нет недостатка в коллективных буйствах толпы».

Что касается России, то подъем общественного самосознания, развитие освободительного движения диктовал необходимость обращения к феномену толпы и русских исследователей (Н.К. Михайловский).

В данной статье мы ограничимся анализом работ исследователей франкоитальянской школы.

При всех различиях в акцентации внимания на различных сторонах указанного явления, интерес ученых концентрировался на свойствах толпы, механизмах коллективной агрессии. Многие исследователи были озабочены необыкновенной силой экзальтации и кровожадности, которые демонстрировали женские толпы, и той весомой ролью, которую играли женщины в гетерогенных скопищах.

Заслуга в постановке проблемы женского фактора в революционных событиях принадлежала И. Тэну. По мнению французского историка, женщины приняли активное участие, как в подготовке революции, так и в ее событиях. В XVIII в., утверждал он, именно женщины были королевами, устанавливали моду, руководили разговорами, следовательно, идеями, а значит и мнениями. В событиях 5-6 октября 1789 г., как следует из II тома «Происхождения современной Франции» И. Тэна, именно женщины выступили в качестве авангарда событий. В отношении мужской части исследователь использовал любопытный оборот: «... мужчины, - писал он, сопутствуют им (женщинам - Г.Б.). И. Тэн первым обратил внимание на свирепость и ярость, характеризующие поведение женщины в толпе. «Мы принесем на конце копья голову королевы», «Ее (про ту же королеву - Г.Б.) надо задушить и наделать кокард из ее кишок», «Где эта мерзавка?» (объект ненависти - прежний - Г.Б.). Надо съесть ее 
сердце» - вот отдельные фразы, которые приводил ученый, утверждая, что в возбужденной до крайности толпе, под влиянием общей заразы (позднее Г. Тард использовал понятие «подражание») проявляется разнузданность пороков, которые раньше сдерживались остатками стыдливости.

Заметим, что И. Тэн не исследовал глубоко механизмы агрессивного поведения женщин в толпе. Это сделали его младшие современники, имена которых уже прозвучали выше. Все они признавали видную роль женщин в революциях. Более того, Ч. Ломброзо и Р. Ляски настаивали на первостепенной роли женщин в восстаниях и толпах, а Г. Тард называл их «ближайшими виновниками революций в цивилизованных странах». Способность женщин выступить в качестве дрожжей толпы, увлечь своим примером мужчин, социологи франко-итальянской школы объясняли особенностями женской психики, преобладанием чувства над разумом. По словам О Кабанеса и Л. Насса, женщины превосходят мужчин храбростью, самопожертвованием, жестокостью, исступленостью и изуверством. В силу своей преимущественно инстинктивной и раздражительной натуры женщины, утверждали Ч. Ломброзо и Р. Ляски, склонны к преувеличениям, как в добре, так и во зле. На чисто физическое влияние, обусловленное особенностями в жестах, чертах лица и в самом строении тела, совмещенное с половым влечением, указывал Г. Тард. «Не от того ли зависит, - писал он, - что когда в толпу или тайное общество замешиваются женщины и сила их обаяния присоединяется к угрозам и насилиям толпы, то сопротивление со стороны отдельных членов этому двойному влиянию становится почти немыслимым».

Психологическим механизмом, который приводит скрытые пружины женской натуры в движение, ученые считали подражание. По мнению Г. Тарда, взаимное возбуждение в толпе напоминает бурные вспышки. В результате индивид утрачивает свои отличительные особенности, поле его сознания значительно сужается, происходит быстрый упадок нравственности, потеря индивидуальной свободы и растворение индивида в массе. Все указанные негативные процессы протекают у женщин намного стремительнее, поскольку они, как утверждали О. Кабанес и Л. Насс, «в высшей степени податливы внушению и представляют легкую добычу для умственной заразы». Любопытно, что исследователи указывали на роль, которую играют мужчины в этом падении женщин на несколько ступенек вниз по лестнице цивилизации. Так, Г. Тард признавал врожденное нравственное превосходство женщин и писал о развращающем влиянии на них мужчин. Характеризуя поведение женщин в толпе, французский социолог указывал, что в этом случае происходит подбор всего, что есть в них наглого, наиболее смелого, мужского. Ч ломброзо и Р. Ляски обращали внимание на тот факт, что когда страсти разнузданы и поддерживаются мужчинами, женщины способны зайти гораздо дальше последних на пути безумия.

Участи е женщин в революциях означало, что они активно включились в политику. Для многих это было неожиданностью. До середины XVIIІв. Политическая деятельность была уделом аристократок. Даже на заре Великой французской буржуазной революции ничто, по словам О Кабанесса и Л. Насса, не давало оснований предвидеть смелого вторжения простых парижанок в политику. Тем не менее, женщины вступили в революцию и с первых же шагов стали играть в ней весьма значительную роль. Данный феномен требовал оценки. Отрицательное отношение исследователей франко-итальянской школы к революциям вообще определило и негативную оценку роли женщин в них. Это нашло отражение уже в словосочетаниях, которые использовали ученые в отношении участниц революционных событий: боевые бабы, мегеры гильотины, роялистские фурии и мужеподобные ведьмы». «Все одинаковы, - заключали О. Кабанес и О. Насс, - когда начинают вмешиваться в политические дела».

Нелицеприятные характеристики, на наш взгляд, были обусловлены не только чрезвычайной экзальтированностью женщин в революционной толпе. Сюда 
примешивалась определенная доля мужского шовинизма. Не случайно в совместных работах Ч. Ломброзо и Р. Ляски, О. Кабанеса и Л. Насса поднималась проблема гендерного равноправия, в том числе в политике. Впервые в наиболее острой форме эта тема прозвучала во время буржуазных революций. Оба исследовательских дуэта апеллируя к радикализму женщин, склонности к чрезвычайному моральному возбуждению, фактически выступили противниками идеи равноправия полов, хотя сделали это в завуалированной форме. «Нельзя отрицать, - писали О. Кабанес и Л. Насс, - что подчас они (женщины - Г.Б.) были способны на великие самоотверженные подвиги и на геройские жертвы, но сколько одновременно проявлялось чудачеств, эксцентричности, изуверства, творческих нелепостей? Невольно задумаешься, какя осторожность нужна при обсуждении вопроса о женском равноправии, и какой еще длинный путь предстоит совершить женщине для достижения столь желанного равенства с сильным полом».

$$
* * *
$$

1. Кабанес О., Насс Л. Революционный невроз. - М.: КСП+, 1998. - С.556.

2. Ломброзо Ч., Ляски Р. Политическая преступность и революция по отношению к праву, уголовной антропологии и государственной науке. В 2 ч. - СПб.: Тип. И.В Шестаковского, 1907. - Ч.1. - С.116.

3. Московичи С. Век толп (Исторический трактат по психологии масс» - М.: Центр психологии и психотерапии, 1998. - С.80.

4. Сигеле С. Преступная толпа. Опыт коллективной психологии /Преступная толпа. - М.: КСП+, 1999. - C.13.

5. Тард Г. Преступления толпы. - Казань: Тип. Императорского ун-та, 1893. - С.28.

6. Тард Г. Преступник и преступление. - М.: Тип. И.Д. Сытина, 1906. - С. 162.

7. Тард Г. Мнение и толпа / Психология толп. - М.: КСП+, 1999. - С.278.

8. Тэн И. Происхождение современной Франции. В 3 т. - СПб., 1907. -Т.1. - С.217. 


\title{
РАЗДЕЛ ІІІ. ПОЛИТОЛОГИЯ
}

\author{
Марабян К.П. \\ Закавказский вектор политики НАТО
}

$O O O$ «CK Аpм-Ka»

(Россия, Чехов)

doi:10.18411/spc-01-08-2019-04

idsp: sciencepublic-01-08-2019-04

\section{Аннотация}

В статье рассматриваются основные аспекты политики Североатлантического альянса в регионе Южного Кавказа (Закавказья), с точки зрения региональной и международной безопасности.

Ключевые слова: региональная безопасность, Южный Кавказ (Закавказье), НАТО, международная безопасность, военно-политическое сотрудничество

После распада Советского Союза и ликвидации Организации Варшавского договора (ОВД) в 1991 г., НАТО встала перед дилеммой о своей роли в Европе и в мире. Исчезновение главного врага означала либо ликвидацию самого НАТО, либо ее трансформацию.

В Стратегической концепции НАТО 1991 г. отмечалась необходимость преобразования организации в соответствии с новой обстановкой и развитием сотрудничества со странами Центральной и Восточной Европы (ЦВЕ). НАТО пришлось отказаться от концепции декларированного противника, и взять курс на развитие отношений с государствами бывшего социалистического лагеря и постсоветского пространства через механизм «Партнерство ради мира» и интеграцию стран ЦВЕ. Партнёрство ради мира (Partnership for Peace - PfP) - программа, созданная в 1994 г. для военного сотрудничества со странами Европы и бывшего СССР, которые не являются членами организации.

Стратегическая концепция НАТО - официальный документ, в котором обозначаются долгосрочные цели и основополагающие задачи альянса в сфере безопасности. В ней охарактеризуются новые условия безопасности, уточняются основы подхода НАТО к вопросам безопасности и представляются также указания по дальнейшему развитию вооруженных сил НАТО.

В Стратегической концепции 1999 г. термин «трансформация» уже не встречается, а используется термин «адаптация». В данной концепции государствачлены НАТО обязались принять участие в обеспечении всеобщей обороны, стабильности и мира в евроатлантическом регионе [3]. В основу документа легло широкое определение понятия безопасности, признавшее помимо оборонного измерения также важность политических, экономических, социальных и экологических факторов. В концепции отмечалось, о том, что НАТО сумела адаптироваться и продолжает играть важнейшую роль в обстановке, которая сформировалась по окончании холодной войны. Концепция призывала к дальнейшему увеличению военного потенциала альянса, необходимого при выполнении ряда задач Североатлантического альянса, начиная с коллективной обороны и заканчивая операциями по поддержанию мира и кризисному реагированию.

В Стратегической концепции 1999 г. было отмечено, что НАТО остается открытой для принятия новых членов. И в том же в 1999 г. в рамках четвертого расширения членами НАТО стали Польша, Венгрия и Чехия. Актуальным же для стран 
Южного Кавказа является пункт о программе «Партнерство ради мира». Страны Южного Кавказа участвуют в данной программе с 1994 г.

19 - 20 ноября 2010 г. в Лиссабоне состоялся саммит НАТО. К этому времени уже прорабатывалась новая концепция НАТО. И на саммите в Лиссабоне новая Стратегическая концепция Североатлантического альянса «Активное вовлечение, современная защита» была принята. Стратегическая концепция 2010 г. - документ о важнейших принципах и задачах НАТО, ее ценностях, быстро меняющихся условиях безопасности и ее стратегических целях, и задачах.

С точки зрения Стратегической концепции 2010 г., евроатлантический регион находится в состоянии мира и угроз конвенциональной атаки территории стран-членов НАТО нет. Однако есть потенциальные угрозы мировой стабильности и глобальной безопасности. Среди таких угроз - распространение оружия массового поражения. А непосредственной угрозой странам-членам НАТО является терроризм. Страны НАТО зависят от международных транзитных путей и коммуникаций, и дестабилизация ситуации в таких регионах непосредственно влияет на безопасность стран НАТО. И НАТО, обладая уникальным набором политических и военных средств для урегулирования широкого круга кризисов - до, во время и после конфликтов, будет активно задействовать соответствующий набор политических и военных инструментов для урегулирования развивающихся кризисных ситуаций, потенциально способных повлиять на безопасность альянса, прежде чем они обострятся до конфликтов; останавливать текущие конфликты там, где они затрагивают безопасность альянса; а также содействовать закреплению стабильности в постконфликтных ситуациях там, где это способствует евроатлантической безопасности. В новой концепции подчеркнут принцип коллективной обороны в соответствии с Вашингтонским договором.

Для стран НАТО важно сохранение паритета ядерного оружия в мире, устранение угроз терроризма, сохранение энергетической безопасности. И регион Южный Кавказ представляет собой площадку на стыке этих проблем и угроз. Находясь на границе с Ираном, с ее ядерной программой, поблизости от центров международного терроризма на Ближнем Востоке и Афганистане, Южный Кавказ также является регионом транзита углеводородов в Европу, а также потенциальным транзитом энергоносителей из Ирана и Средней Азии в Европу. И естественно НАТО очень активно действует в данном регионе [1, с. 30]. Из стран Южного Кавказа наиболее тесные отношения с НАТО сложились у Грузии, хотя и Армения, и Азербайджан активно сотрудничают с НАТО. Однако только Грузия изъявила желание стать полноправным членом НАТО.

Поэтому можно особо отметить сотрудничество Грузии с НАТО. Начало отношениям между НАТО и Грузией было положено в 1992 г. со вступлением Грузии в Совет североатлантического сотрудничества (переименованный в 1997 г. в Совет евроатлантического партнерства). С присоединением Грузии к программе «Партнерство ради мира» в 1994 г. и к Процессу планирования и анализа ПРМ (ПАРП) в 1999 г. сотрудничество углубилось и расширилось. Уже со второй половины 90-х годов XX века грузинские политики связывали решение абхазской проблемы с политикой НАТО и США в регионе. Для грузинского руководства до «революции роз», и особенно после было важно военное присутствие НАТО в Грузии. Руководство Грузии во главе с М. Саакашвили попытались заменить миротворческие силы в конфликтных зонах на соответствующие контингенты НАТО. Однако России удалось отстоять свое миротворческое присутствие в регионе. Отчасти и поэтому стал возможен Кавказский кризис 2008 г. Однако НАТО открыто поддерживала Грузию как во время Кавказского кризиса 2008 г., так и после него. 2-4 апреля 2008 г. в Бухаресте прошел саммит НАТО. Президент США Дж. Буш призывал союзников по НАТО позволить Грузии присоединиться к Плану действий по членству в НАТО. Однако некоторые страны Европы, в т. ч. Франция и Германия опасались реакции России. И 
Грузию не допустили к Плану действий по членству. Однако Грузия, также, как и Украина получили заверения в том, что они, в конечном счете, присоединятся к союзу, как только они будут отвечать требованиям членства. Важную роль в осмыслении роли НАТО на Южном Кавказе и возможных последствий в случае принятия плана по вхождению Грузии в НАТО сыграл Кавказский кризис 2008 г. [4, с. 48]

В сентябре 2008 г. была создана Комиссия НАТО - Грузия (КНГ), призванная оказывать помощь Грузии после конфликта с Россией, а также процессом, начало которому было положено на встрече в верхах в Бухаресте. Важным направлением сотрудничества является также поддержка со стороны Грузии операций под руководством НАТО. Грузия вносит активный вклад в действия Международных сил содействия безопасности (International Security Assistance Force (ISAF)) в Афганистане. Грузия также участвует в Операция «Решительная поддержка». Несмотря на различные программы и помощь со стороны НАТО Грузии, в обозримом будущем членство Грузии в НАТО выглядит нереальным. Главную роль в этом сыграли итоги Кавказского кризиса 2008 г., трезвый анализ которых в 2008-2009 гг. на Западе привели к осознанию роли России в регионе. И теперь США и ее союзникам по НАТО приходится учитывать фактор России.

Азербайджан и Армения также активно сотрудничают с НАТО. Азербайджан с момента обретения независимости активно сотрудничает в военно-технической и военно-политических сферах с Турцией, государством-членом НАТО. С 1994 г. и Армения, и Азербайджан присоединились к «Партнёрству ради мира» (англ. Partnership for Peace - PfP), программе, созданной в 1994 г. для военного сотрудничества Североатлантического альянса с европейскими государствами и с республиками Южного Кавказа и Центральной Азии, не являющимися членами НАТО. Азербайджан, установив тесные связи с Турцией, активно начала сотрудничать в военной сфере с США, а затем и с Израилем. Азербайджанский миротворческий контингент принимал участие в операциях НАТО в Косове с 1999-200 гг. В составе Международных сил содействия безопасности (ISAF) в Афганистане несут службу и подразделения вооруженных сил Азербайджана [5].

НАТО оказывает поддержку в реформировании системы безопасности в Азербайджане. Другой важной целью сотрудничества НАТО с Азербайджаном состоит в том, чтобы развивать способность вооруженных сил страны к взаимодействию с силами стран НАТО. Таким образом, вооруженные силы Азербайджана будут реформироваться по стандартам НАТО. Азербайджан стремится к укреплению безопасности своего морского пространства и своих возможностей на море, необходимых для снижения незаконной деятельности в Каспийском море, и в этих целях сотрудничает с рядом государств-членов НАТО. НАТО также поддерживает работу, направленную на укрепление безопасности границ Азербайджана.

Армения также активно развивает свои отношения с НАТО, однако официально заявляя о том, что становиться членом Альянса Армения не намерена. Армянские миротворцы также участвуют в миротворческих операциях НАТО в Косове и Афганистане.

Армения проводила консультации с государствами-членами НАТО в процессе о разработки Стратегии национальной безопасности и новой Военной доктрины. При сотрудничестве НАТО и Армении в Ереване создан ситуационный центр, предназначенный для координации регулирования кризисов и контртеррористической деятельности.

Армения намерена совершенствовать свою готовность к чрезвычайным ситуациям и создать потенциал для реагирования на бедствия и катастрофы. Спасательная служба Армении приняла ряд мер по усовершенствованию планирования действий в сложной обстановке и активно принимает участие в создании государственного центра для кризисного регулирования. Армения также углубляет 
связи с функционирующим при НАТО Евроатлантическим координационным центром реагирования на стихийные бедствия и катастрофы (ЕКЦРСБК), внося свой вклад в международные операции по оказанию помощи при стихийных бедствиях. Спасательная служба Армении готовит два отряда (поисково-спасательный отряд и отряд специалистов по химической, биологической, радиационной и противоядерной защите), которые можно будет привлекать к ликвидации последствий стихийных бедствий и катастроф. В Ереване с 2007 г. действует Информационный центр НАТО.

Регион Южного Кавказа является одним из важнейших звеньев в политике НАТО в регионе Большого Ближнего Востока. Энергетическая безопасность является общей серьезной проблемой безопасности. По территории Южного Кавказа, проходят маршруты транспортировки нефти и газа. К тому же регион является связующим звеном между Европой и Афганистаном, где НАТО все еще проводит операции. Исходя из этого, НАТО и впредь намерена углублять сотрудничество со странами Южного Кавказа. Однако пока о членстве в НАТО речи не идет даже для Грузии.

Грузия и Азербайджан надеялись, что сближение с Соединенными Штатами и НАТО поможет решить их территориальные проблемы, в том числе силовым путем, и гарантирует их безопасность. На смену ограниченного привлечения республик Южного Кавказа к программам НАТО пришла политика активного втягивания Грузии и Азербайджана в альянс. Однако статус-кво в регионе сохраняется до сих пор. Все три страны региона Южного Кавказа активно сотрудничают с НАТО. Однако в ближайшее время существенных изменений в структуре безопасности на Южном Кавказе не предвидится.

Армения и Азербайджан имеют глубокие связи с структурами НАТО. Армения, являясь членом ОДКБ, а с 2015 г. и членом ЕАЭС, сотрудничая с НАТО, декларирует неприсоединение к этой организации в качестве полноправного члена. Азербайджан также заинтересован в углублении отношений с структурами НАТО. Однако Азербайджан старается иметь хорошие отношения со всеми центрами силы. Азербайджан активно сотрудничает с Россией во всех сферах, но намерений вхождения в евразийские интеграционные проекты не имеет в настоящее время. Не декларирует Азербайджан и стремления к членству в НАТО. Азербайджану, имеющего существенные запасы углеводородов, выгодна ситуация частичного нейтралитета. Грузия, имея на своей территории частично признанные государства, стать членом НАТО не может. Ей придется либо официально отказаться от Абхазии и Южной Осетии и войти уже без них в НАТО, либо придется ждать урегулирования этих вопросов.

$$
* * *
$$

1. Марабян К.П. Политика США в регионе Южного Кавказа /К.П. Марабян// Национальная безопасность и стратегическое планирование. - 2016. - № 1. - С. 28-33.

2. Новая Стратегическая концепция НАТО «Активное вовлечение, современная защита» [Электронный pecypc] // Официальный сайт НАТО - Режим доступа: http://nato.ucoz.ru/index/strategicheskaja_koncepcija_nato_2010_goda/0-39 (дата обращения: 25.02.2015г.)

3. Смирнов П.Е. Новая стратегическая концепция НАТО и место в ней стран-партнеров [Электронный ресурс] // Институт США и Канады РАН. - 1999 г. - Режим доступа: http://www.iskran.ru/russ/works99/smirnov.html (дата обращения: 09.06.2019г.)

4. Штоль В.В. О новой стратегической концепции НАТО /В.В. Штоль// Научно-аналитический журнал «Обозреватель - Observer». - 2010. - №8 (247). - С. 47-56.

5. International Security Assistance Force (ISAF): Key Facts and Figures [Электронный pecypc] // Official website NATO. - Режим доступа: http://www.rs.nato.int/images/media/20140603_isaf-placemat-final.pdf (дата обращения: 01.03.2015г.) 


\section{Фокина О.А.}

\section{Сервисная политика государства как механизм политического маркетинга}

ФАОУ ВО «Волгоградский государственный университет»

(Россия, Волгоград)

doi:10.18411/spc-01-08-2019-05

idsp: sciencepublic-01-08-2019-05

Государство как центральный, интегрирующий общество политический институт сохраняет традиционные признаки и функции, которые описаны еще в концепции М.Вебера [3; 4], однако изменяющиеся функции и механизмы их реализации на современном этапе свидетельствуют и о новом качестве государства, обновлении его сущности. Одной их особенностей глобальной политикоадминистративной реформы является стремление перестроить государственное управление по подобию маркетинга и менеджмента (менеджеризация государственного управления), реализуемого в рамках частного бизнеса, который характеризуется достаточно высоким уровнем корпоративного управления с четким распределением функциональных обязанностей на всех уровнях управления бизнесом. Также своеобразная «сервисная революция» заставила производителей товаров и услуг стремиться к предоставлению высококачественного сервиса - изменились основы конкурентной борьбы: от конкуренции ценой - к конкуренции качеством, в том числе качеством обслуживания и установления долгосрочных отношений с клиентами. Маркетинг отношений, построенный на четырех основаниях - гарантии, отзывчивость, взаимность, доверие, - стратегически направлен на установление долгосрочных взаимоотношений между производителем и потребителем, на сохранение партнеров и потребителей, что стоит гораздо меньше, чем их поиск и приобретение; именно долгосрочные отношения являются в современном обществе решающим фактором сотрудничества и конкуренции, в том числе в сфере политики.

В научной социально-политической литературе практически отсутствует понятие «сервисная политика», за исключением незначительного количества работ, посвященных развитию сервиса в РФ $[1 ; 12 ; 13]$, который рассматривается шире, чем сфера предоставления государственных услуг. Вышеуказанные авторы, а также ряд исследователей социально-экономических процессов в постиндустриальном обществе [5; 11] либо определяют сервис как социальный институт, формирующийся в условиях сервисизации различных сфер общественной жизни не только в России, но в других странах, либо прямо указывают на институциональные черты сервиса в условиях становления общества потребления.

Идея управляемости процессом предоставления социальных благ (в том числе услуг, гарантированных государством) со стороны власти содержится в ряде исследований, посвященных теории «социального государства». Для темы данной работы интересным представляются идеи Л. фон Штейна, высказанные им еще в конце XVIII в. Несмотря на то, что в его работах нет понятия «услуга», «сервисная политика», основная идея - признание и закрепление со стороны государства своих обязанностей перед гражданами - являются основанием для понимания сути сервисной политики [14; 15]. Определяя сущность социального государства и роль власти, Штейн подчеркивал, что государство обязано поддерживать социальное равенство всех граждан, «способствовать экономическому и общественному прогрессу всех своих граждан, ибо... развитие одного выступает условием развития другого» [9; с.82], и в этом заключается долженствующая функция государства. В то же в рамках теории политического маркетинга, основанной на идеях общественного договора, политический обмен голосами избирателей и услугами государства должен 
обеспечивать легитимацию власти и приводить к стремлению государства заботиться о благополучии своих граждан.

Лоренц фон Штейн, размышляя о социальной функции государства, отрицает альтруистическое начало в его деятельности: государственной власти необходимо чувствовать свою политическую защищенность, поэтому политическая стабильность достигается в служении своему народу, в обязанности заботиться о гражданах посредством реализации социальных функций - предоставление помощи от государства не в виде милостыни, а в виде социальных гарантий, обеспечения социально незащищенных граждан. Поэтому борьбу за свое существование на определенных этапах своего развития государство будет осуществлять не на языке политических идей и политического противостояния, а путем установления долгосрочных взаимоотношений государства с гражданами, направленных на обеспечение реальных интересов населения: удовлетворенные уровнем и качеством жизни, граждане не станут стремиться к радикальному изменению своего положения именно этим достигается социально-политическая стабильность. Штейн писал: «чем ничтожнее его [государства - выделено нами] граждане, тем оно само ничтожнее; чем меньше они развиты, тем менее развито само государство» [14; с.28].

Таким образом, задача любого государства - это установление сбалансированности интересов различных социально-политических акторов, и в современных условиях меняется не цель, а содержание его функций и их название. Вряд ли в ближайшем будущем достижима цель - устранение «социального неравенства, обеспечение всеобщей [выделено нами] доступности социальных благ» [14; c.28], т.к. полное совпадение интересов личности и государства вряд ли возможно. Однако исполнение государством своих функций в социальной сфере, как указывал Штейн, своеобразное «служение» обществу, «обслуживание» социальных потребностей граждан определяет политическую стабильность и снижает протестные настроения, создает условия для реализации индивидуальных потребностей и запросов.

В связи с вышесказанным политика государства приобретают новое содержание и находит отражение в следующих функциях:

1) ограничительная функция, которая проявляется в ограничении монополизации и регулировании экономики, регламентации трудовых отношений, концентрации ресурсов на социальные программы и нужды;

2) обеспечительная функция, направленная на реализацию социальных задач социальное страхование и социальное обеспечение, гарантии получения гражданам образования и услуг здравоохранения;

3) гарантирующая функция: государство на конституционном уровне гарантирует своим гражданам обеспечение системы гражданских прав, более того, государство не просто предоставляет систему государственной социальной поддержки, помощи, но становится должником своих граждан, потому что не выполнить конституционно закрепленные гарантии оно уже не может [6].

Данный вывод поддерживается основными идеями теории постиндустриального общества. Так, по мнению Д. Белла, рост благосостояния населения приведет к увеличению спроса на личные услуги, что обусловит развитие сервисного сектора, а широкое применение информационных технологий приведет и к структурным изменениям в политической сфере: утверждение плюралистической демократии будет способствовать повышению эффективности работы государственных институтов и структур [5], направленной на повышение качества сервисной политики и легитимации власти.

Применительно к самой дефиниции «сервис» в научном знании существует множество подходов его определения. Исторически сложившееся понимание сервиса как третичного сектора экономики затрудняет, на наш взгляд, понимание сути сервисной политики государства. В объяснении генезеса сервиса доминирует 
смитовская теория общественного разделения труда, согласно которой сервис возник и развивался в условиях растущей дифференциации трудовой занятости населения и выделился в отдельную сферу общественно-экономической деятельности как непроизводственный сектор [10]. Английский историк Р.М. Халтуэлл связал стремительное развитие экономики нового времени с «революцией услуг» [цит. по 11; c.41]. Согласно классической схеме стадиального развития общества К.Кларка [16], изменение профессиональной структуры общества шло по линии перераспределение трудовых кадров от первичного к вторичному и от вторичного к третичному сектору, однако важность развития третичного сектора при конструировании моделей общественного развития, как отмечает Ф. Бродель, мало кто подчеркивает. О государственном регулировании сферы предоставления услуг говорить вообще не приходится в связи с тем, что развитие данной сферы, согласно А.Смиту, происходит под влиянием «невидимой руки рынка»: есть спрос на какие-либо услуги - они появляются как доходный сегмент экономической деятельности. Задача государства в таком случае заключалась в налоговом контроле дохода лиц и предприятий, оказывающих услуги населению. Таким образом, сервис формируется исторически наряду с древнейшими формами производства, а не следует стадиально за ними.

В современном обществе без сервиса ни одна из сфер общественного бытия экономического, социального, культурного, политического - также несостоятельна. В связи с этим следует говорить о возможности и необходимости управления сервисом со стороны власти как одной из функций политического маркетинга, особенно если это касается социального благополучия граждан, на которое влияет спектр и качество оказания услуг, в том числе гарантированных государством.

При определении дефиниции «сервисная политика» малопродуктивным, на наш взгляд, является широко распространенное в политологии понимание политики М. Вебером как «стремления к участию во власти или к оказанию влияния на распределение власти, будь то между государствами, будь то внутри государства между группами людей, которые оно в себе заключает» [2; с. 646], в силу того что содержательно сервисная политика предполагает отношения между индивидами / социальными группами и государством по поводу условий их жизнедеятельности. С точки зрения социальной сущности политики, власть выступает как универсальный механизм согласования и упорядочения интеракций людей, которые реализуют собственные интересы, т.е. является механизмом интеграции интересов и запросов граждан. Следовательно, наиболее продуктивным в рамках данной работы является понимание политики как сферы отношений и деятельности, включающей в себя всё, «что обеспечивает или препятствует реализации общих интересов социальных групп и сообществ, все, что связано с человеческими ценностями: свободой, социальной справедливостью, социальным процессом» [7; с.364].

Таким образом, понятие «сервисная политика» отражает деятельность, в рамках которой государство выступает, во-первых, субъектом разработки и реализации услуг, гарантированных государством, в том числе посредством информационных и телекоммуникационных систем; во-вторых, субъектом регулирования социальноэкономических и политических взаимодействий и отношений в сфере предоставления населению социально значимых услуг, в-третьих, субъектом политических маркетинговых отношений.

Содержательно сервисная политика во многом близка социальной политике, однако не тождественна ей: социальная политика - часть сервисной политики в силу того, что реализация сервисной политики не ограничивается оказанием социально значимых услуг населению. Речь идет о консолидации ресурсов власти, бизнеса и структур гражданского общества для развития сервисной сферы как основы социального благополучия, обеспечивающей социальную справедливость и заботу о 
человеке и среде его жизнедеятельности, эффективность которой придает устойчивость общественно-политическому развитию, легитимирует правящий режим.

$$
\text { *** }
$$

1. Биндиченко Е.В. Социальные проблемы развития института сервиса в условиях трансформации российского общества. - дис. ... д-ра социол. наук. - Уфа, 2001. - 378 с.

2. Вебер М. Избранные произведения. - М.: Прогресс, 1990. - 880 с.

3. Вебер М. Политика как призвание и профессия. - М.: Изд-во: Гуманитарный центр, 2018. - 226 с. (офсет)

4. Вебер М. Хозяйство и общество: очерки понимающей социологии [Текст] : в 4 т. / Макс Вебер ; [пер. с нем.] ; сост., общ. ред. и предисл. Л. Г. Ионина; Нац. исслед. ун-т «Высшая школа экономики». - М. : Изд. дом Высшей школы экономики, 2016. - Т1. Социология. -445 с.

5. Д. Белл. Грядущее постиндустриальное общество. Опыт социального прогнозирования. - М.: Academia, 2004. - $944 \mathrm{c}$.

6. Кочеткова Л.Н. Теория социального государства Лоренца фон Штейна // Философия и общество. Выпуск № 3 (51) / 2008. [Электронный ресурс] - Режим доступа: https://www.socionauki.ru/journal/articles/130203/, открытый

7. Ледяев В. Г. Власть: концептуальный анализ. - М.: РОССПЭН, 2001. - 380 с.

8. Македонская Ж.Х. правовая природа Российской Федерации как социального государства: дис. ...канд.юр.наук. - М.: 1997. - С.57.

9. Милецкий В.П. Социальное государство: эволюция идей, сущность и перспективы становления в современной России // Политические процессы в России в сравнительном измерении. - СПб.: Издво С.-Петерб. ун-та, 1997. - С.82.

10. Смит А. Исследование о природе и причинах богатства народов. - М.: Эксмо, 2007. - (Серия: антология экономической мысли). -960 с.

11. Федулин А.А., Багдасарян В.Э. Сервис в историческом и философском осмыслении. - М.: Собрание, 2010. -240 c.

12. Фокина О.А. Институт сервиса и потребительское поведение граждан: специфика трансформации в современной России: монография. - Волгоград: Изд-во ВолГУ, 2014. - 293 с.

13. Хмелев В.В. Социальный институт сервиса в современном российском обществе: теоретикометодологические основы исследования: автреф. дис. ... д-ра социол. наук. - М., 2001. - 38 с.

14. Штейн Л. История социального движения Франции с 1789 г.: Пер. со 2 нем. изд. Т.1. / Л. Штейн Основное понятие общества и социальная история Французской революции до 1830 года. - СПБ.: Тип. А.М. Котомина, $1872 .-305$ с.

15. Штейн Л. Учение об управлении и право управления с сравнением литературы и законодательства Франции, Англии и Германии. - СПб.: Гиероглиф, 1874. - 578 с.;

16. Clark C. The Condition of Economic Progress. - London: Mc. Millan, 1940. - 212 p. 


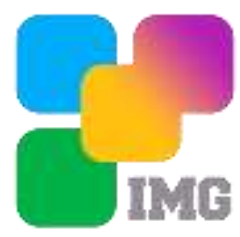

Научное издание

Научный диалог:

Вопросы философии, социологии, истории, политологии

Сборник научных трудов, по материалам XVII международной научно-практической конференции

1 августа 2019 г.

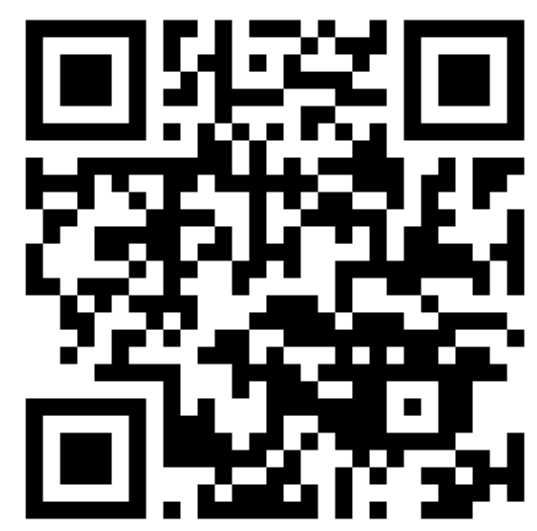

SPLN 001-000001-0500-FI

Подписано в печать 07.08.2019. Тираж 400 экз.

Формат.60х841/16. Объем уч.-изд. л. 1,38

Бумага офсетная. Печать оперативная.

Отпечатано в типографии НИЦ «Л-Журнал»

Главный редактор: Иванов Владислав Вячеславович 